\title{
Formation of Meta-Subject Results in Teaching a Foreign Language
}

\author{
Lilia Rashidovna Mustafina $^{1} \&$ Liliya Rustamovna Slavina ${ }^{1}$ \\ ${ }^{1}$ Kazan Federal University, Russia \\ Correspondence: Lilia Rashidovna Mustafina, Kazan Federal University, Russia. E-mail: LRMustafina@kpfu.ru
}

Received: September 7, 2020

Accepted: October 27, 2020

Online Published: October 31, 2020

doi:10.5430/ijhe.v9n8p59

URL: https://doi.org/10.5430/ijhe.v9n8p59

\begin{abstract}
The modern system of national education, developing in the competence paradigm, puts on the agenda the need to form students' communicative skills that belong to the category of critical competencies of a meta-subject nature. The article discusses the methodological features and pedagogical conditions for forming meta-subject skills of schoolchildren in foreign language lessons. An attempt is proposed to determine the characteristics of the meta-subject approach, including a complex of personality traits that allow the student to act in a given communication situation at the level determined by the age-related psychological characteristics and the possibilities of the social experience of a younger student. The authors used the following research methods: utilizing the study and generalization of pedagogical experience and the survey method, the communicative, regulatory - behavioral and motivational characteristics of a younger student, which must be taken into account when introducing pedagogical technologies focused on meta-subject results in foreign language lessons, are concretized, The analysis of the real practice of an educational activity is aimed at establishing a set of features of the pedagogical support of the meta subject approach within the framework of the "Foreign language" discipline in primary school. Based on the analysis of scientific literature on research and practical experience, several strategies have been identified that ensure the effective implementation of meta-subject results in younger students in foreign language lessons.
\end{abstract}

Keywords: meta-subject, competence, the cognitive component, motivational component, communication skills, teaching foreign languages, regulatory, and behavioral component

\section{Introduction}

The 21 st-century society is characterized as a knowledge society or an information society where information is the critical element of production and, undoubtedly, has the highest economic value in globalization's current conditions. Knowledge, independent acquisition, and information processing are becoming less and less the prerogative of school education: competitiveness in the modern labor market means mastering and handling unique knowledge (Tan et al., 2018). The ability to learn (self-education) is a necessary factor in personal growth and a subsequent professional demand guarantee. This postulate defined the concept of "Lifelong learning" of UNESCO World Report «Towards Knowledge Societies» (UNESCO World Report), in which one of the key competencies is the LEARNING-TO-LEARN competency. Modern realia and technological progress determine the traditional education model's failure, where the teacher conveys existing knowledge, and the student in their turn is a passive object of learning (Kordts-Freudinger, 2017). The rapid obsolescence of knowledge shows that the ability to learn and critically comprehend the huge amount of information available is necessary for a modern individual (Handabur et al., 2020).

Designed in 2010, the second-generation federal state educational standard identifies individual and meta-subjects results as key learning outcomes (along with traditional subject ones) (Decree "On the approval of the federal state educational standard of basic general education, 2014). Under meta-subject results, we understand the universal learning activities (ULA) mastered by students, providing mastery of critical competencies that form the basis of learning and intersubject concepts.

In our practice of teaching a foreign language in elementary school, we refer to the Federal State Educational Standard, in which meta-subject educational results are universal methods of activity - cognitive, communicative, standards-compliant, applicable both in the educational process and in solving problems in real-life situations. 
Simultaneously, the Federal State Educational Standards (FSES) of primary general education determines only the requirements for primary school students' planned learning outcomes but does not formulate the learning outcomes themselves. The last is indicated in the basic educational curriculum of primary general education, which presents: basic skills (66) such as 1) identity (13); 2) standards-compliant (9); cognitive (15); 3) communicative (10); 4) reading comprehension (19), as well as ones with advanced skills (44) - "the graduate will have the opportunity to learn". Thus, primary school students should have about 66 to 110 skills by the end of primary school.

The purpose of the experimental part of the work is to determine the degree of formation in primary school students of the skills and abilities proposed by the Federal State Educational Standard (Decree of the Ministry of Education and Science of Russia dated December 31, 2015, N 1577). Our study's special interest is aimed at the formation of communicative competencies as part of meta-subject results in a primary school on the subject of a foreign language. An experiment is proposed in the form of a survey and analysis of training materials, which allows to identify problems in their development and to adjust the educational process in such a way as to ensure the creation of all the planned learning outcomes.

\section{Methods}

Based on the materials and conclusions of the theoretical part of the study, in order to determine the characteristics and level of development of communicative skills of students in primary foreign language education, we have framed a further study in the direction of assessing the level of formation of meta-subject result components, in particular, communicative skills (communicative competence) among students. The study involved 60 primary school students (Russia, the Republic of Tatarstan)

The summative assessment method was chosen for the experiment, the main purpose of which is to establish the presence or absence of the phenomenon under study in certain controlled conditions, measure its quantitative characteristics, and give a qualitative description. Under the studied phenomena, we understand the characteristics of the level of formation of the components of communicative skills in the framework of the meta-subject approach. In foreign language education, traditionally, the main attention is paid to assessing verbal communicative competence, and existing methods allow determining the level of proficiency in it. These methods include T. A. Fotekova (2007) tests, which allow us to determine the cognitive-linguistic component of communicative competence. We also conducted a survey according to the method of A. I. Shemshurina (1996) (modified questionnaire) to identify emotional sensitivity and show the children's knowledge of etiquette formulas and the ability to use them in communication situations. It should be noted that there are some questionnaires and tests to determine personal characteristics in communication, personality and communicative properties, social motivation in the field of communication, self-esteem, self-esteem, self-esteem, and psychological defense. These are, for example, such techniques as SSIC (self-regulation and the success of interpersonal communication), SIT (social intelligence test), COSCOM (a measurement of communicative and social competence). As a result, we used: the methodology of T. A. Fotekova, lexical, and grammatical tests in English to determine the level of formation of the cognitive component of communicative competence in Russian and English. According to A. I. Shemshurina (modified questionnaire) method, a survey was performed to identify emotional sensitivity and empathy. The methodology, which was based on the modified Rene Gille's methodology (Rene Gille's testing methods) and tasks for diagnosing the level of formation of social and communicative competence, was chosen to determine the level of motivational component (by indicators: the need for communication and positive attitude to cooperation) and the regulatory and behavioral component of communicative competence (by indicators: the ability to build their behavior following the communication situation; the ability to take into account the opinion of the interlocutor; the ability to be polite; the ability to empathize with the interlocutor and conflict, aggressiveness). The observation method was used to control students' behavior in various situations of business and free communication to identify the practical use of knowledge and skills for all identified components of communicative competence.

As part of the study, we reviewed and evaluated the formation of the following results:

1. the development of the ability to plan the speech and non-speech behavior;

2. the development of communicative competence 


\section{Results and Discussion}

\subsection{Determining the Level of Formation of Cognitive Skills in the Meta-Subject Framework}

To determine the level of proficiency of fourth-grade students in the Russian language (that is, the level of formation of the cognitive component of communicative competence), the tasks developed by T. A. Fotekova were used. Studying the level of formation of the cognitive component of communicative competence as part of a meta-subject result of fourth-grade students included controlling the formation of the grammatical structure of speech, word-formation processes, speech consistency, understanding of logical and grammatical relationships, as well as knowledge of the most common speech formulas for various communication situations. Three levels were distinguished: high, medium, and low. The table shows the characteristics of different levels. Let us enlarge the characteristics of these levels in Table 1.

Table 1. Characteristics of levels of a meta-subject cognitive component

\begin{tabular}{|c|c|c|}
\hline High level & Intermediate level & Low level \\
\hline $\begin{array}{l}\text { 1. The correct use of words (taking into } \\
\text { account the grammatical features of } \\
\text { various parts of speech). } \\
\text { 2. Spelling rules usage. } \\
\text { 3. The correct position of punctuation } \\
\text { marks. } \\
\text { 4. When checking phrases/sentences, } \\
\text { the ability to find (and correct) errors is } \\
\text { manifested. } \\
\text { 5. Ability to use various language } \\
\text { means. } \\
\text { 6. Rewriting the text in accordance } \\
\text { with the task. } \\
\text { 7. Analysis and correction of the read } \\
\text { text. } \\
\text { 8. The ability to build their own } \\
\text { answer. } \\
\text { 9. The ability to express one's thoughts } \\
\text { in a textual unity. }\end{array}$ & $\begin{array}{l}\text { 1. Words in phrases and sentences } \\
\text { sometimes do not agree } \\
\text { 2. The presence of spelling errors in } \\
\text { unchecked words. } \\
\text { 3. Punctuation is not always correct } \\
\text { 4. The ability to find a mistake only } \\
\text { under the guidance of a teacher. } \\
\text { 5. Limited vocabulary. } \\
\text { 6. Difficulties in the analysis and } \\
\text { correction of the text. } \\
\text { 7. Difficulties in retelling. } \\
\text { 8. Inconsistency, } \\
\text { inconsistency of phrases in the } \\
\text { presentation of their point of view. } \\
\text { 9. The text written by the student is } \\
\text { perceived entirely. }\end{array}$ & $\begin{array}{l}\text { 1. Mistakes in matching words in } \\
\text { phrases and sentences. } \\
\text { 2. Frequent spelling errors. } \\
\text { 3. Major mistakes in punctuation. } \\
\text { 4. Problems with search and } \\
\text { correction of mistakes. } \\
\text { 5. The vocabulary is limited. } \\
\text { 6. Text analysis is successful only } \\
\text { under the guidance of a teacher. } \\
\text { 7. Difficulties in retelling the text. } \\
\text { 8. Answers are usually syllable. } \\
\text { 9. The written text may not } \\
\text { contain an introductory part } \\
\text { connecting words or sentences } \\
\text { and an ending. }\end{array}$ \\
\hline
\end{tabular}

Quantitative and qualitative analysis of the formation of the cognitive component of communicative competence (in the field of the Russian language proficiency) showed the following results: high level - 19\% (12 students); the average level is $54 \%$ (32); low level - 27\%. (16) To determine the level of proficiency of a foreign (English) language of students of the fourth grade, lexical and grammatical testing was conducted. The test included tasks aimed at assessing:

1. Vocabulary (vocabulary; the correct use of words in collocations, set expressions; knowledge of the "functional language" ("functional language" is the "service language" used in assignments when students communicating);

2. Grammar (word order in a sentence; tense forms of verbs; verbs; the use of auxiliary verbs in interrogative and negative sentences; plural forms of nouns; the use of articles.

The levels of formation of the cognitive component of communicative competence (in the field of the English language proficiency) divided up as follows: high level - 17\% (10 students); the average level - 52\% (30 students); low level - $31 \%$ (20 students). 


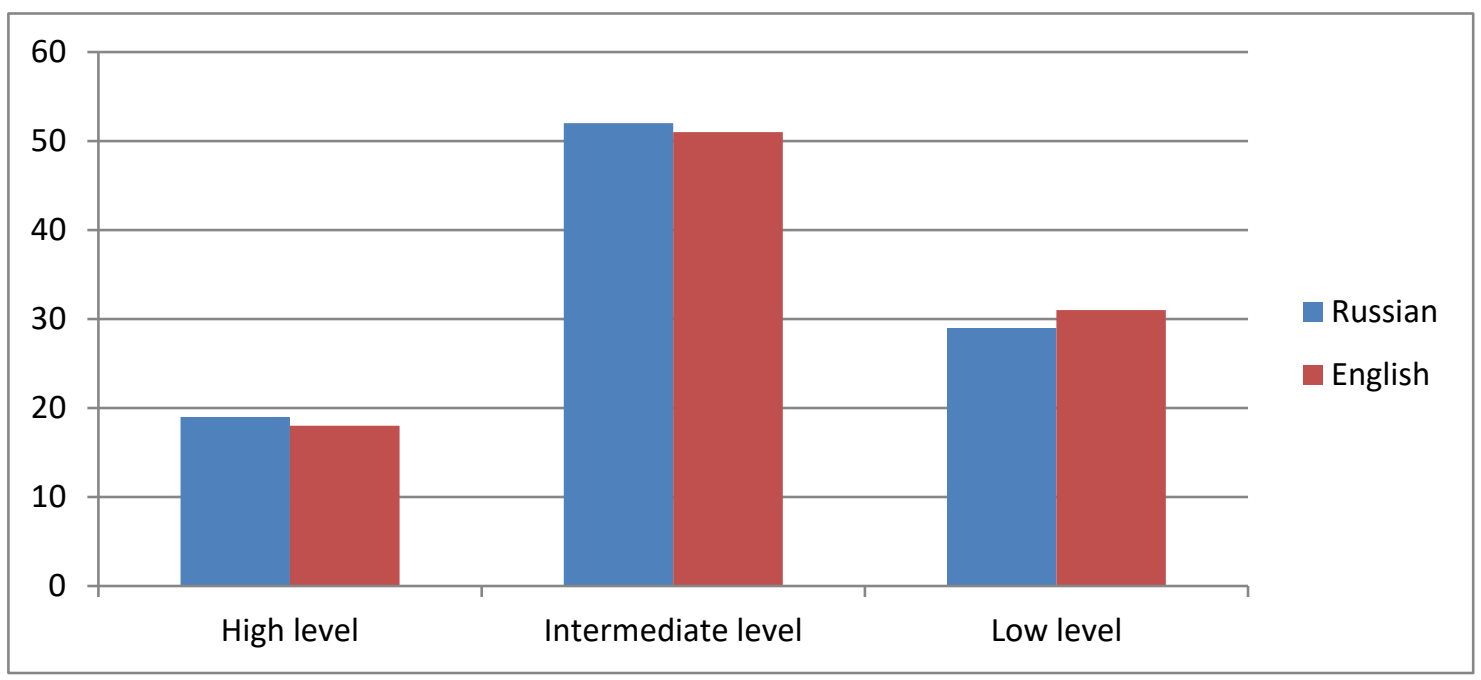

Diagram 1. Comparative analysis of cognitive competencies of primary school students

When comparing cognitive skills assessments, we can say that they are quantitatively close and those who perform well-grounded knowledge in Russian have the same high level of meta-subject cognitive component in English (Diagram 1).

\subsection{Determining the Level of Formation of Conative and Regulatory-Behavioral Components of Meta-Subject}

To determine the maturity level of such components of the meta-subject competence, as motivational and regulatory-behavioral in younger schoolchildren, we used the modified Rene Gilles method and questionnaires according to the method of A. I. Shemshurin (modified questionnaire). These surveys' results answered the questions about how well the children know and use etiquette formulas in communication and revealed emotional sensitivity and ability to empathy. The ability to communicate with a younger student is definitely manifested in family relationships, in relationships with classmates and teachers. The conative component is manifested in communication needs (with peers and adults) and positive (not negative) attitude towards cooperation.

The standard-behavioral component is considered as: - the ability to structure their behavior in accordance with the communicative task and the communication situation; - the ability to listen to the point of view of the interlocutor, even if it differs from their own point of view; the ability to take into account the opinions of other people; - the ability to select words and expressions taking into account the situation of communication; the ability to be polite; the ability to express their attitude to the situation (if necessary) and empathize with the interlocutor.

In assessing students' responses, we used the scale: - characterized positively, - varies depending on the situation / there are some problems - characterized negatively. Based on the test results, we were able to get a reasonably detailed picture of the formation of conative and regulatory-behavioral components of communicative competence. Table 2 proposes summary characteristics of conative and regulatory-behavioral components of the communicative element of meta-subject of 60 students of the fourth grade at the ascertaining stage. 
Table 2. characteristics of conative and regulatory-behavioral components of the communicative element of meta-subject of surveyed students

\begin{tabular}{|c|c|c|c|c|}
\hline Components & \multirow{2}{*}{ Indicators } & \multirow{2}{*}{$\begin{array}{l}\text { The data received } \\
\text { are characterized } \\
\text { positively. }\end{array}$} & \multirow{2}{*}{$\begin{array}{l}\text { The received data } \\
\text { varies depending } \\
\text { on the situation }\end{array}$} & \multirow{2}{*}{$\begin{array}{l}\text { The data received are } \\
\text { characterized } \\
\text { negatively }\end{array}$} \\
\hline Competence & & & & \\
\hline \multirow{4}{*}{ Conative } & $\begin{array}{l}\text { Need for } \\
\text { communication }\end{array}$ & $45 \%$ & $44 \%$ & $11 \%$ \\
\hline & $\begin{array}{l}\text { Positive attitude } \\
\text { towards cooperation }\end{array}$ & $30 \%$ & $40 \%$ & $30 \%$ \\
\hline & $\begin{array}{l}\text { The ability to } \\
\text { structure their own } \\
\text { behavior }\end{array}$ & $19 \%$ & $60 \%$ & $21 \%$ \\
\hline & $\begin{array}{l}\text { The ability to take } \\
\text { into account the } \\
\text { opinion of the } \\
\text { interlocutor }\end{array}$ & $20 \%$ & $57 \%$ & $13 \%$ \\
\hline \multirow[t]{4}{*}{ Regulatory-behavioral } & $\begin{array}{l}\text { The ability to be } \\
\text { polite }\end{array}$ & $40 \%$ & $40 \%$ & $20 \%$ \\
\hline & $\begin{array}{l}\text { The ability to } \\
\text { empathize with the } \\
\text { interlocutor }\end{array}$ & $18 \%$ & $56 \%$ & $36 \%$ \\
\hline & \multirow{2}{*}{$\begin{array}{l}\text { Proneness } \\
\text { conflict, } \\
\text { aggressiveness }\end{array}$} & $\begin{array}{l}\text { Non-conflict } \\
\text { behavior }\end{array}$ & $\begin{array}{l}\text { It depends on the } \\
\text { situation }\end{array}$ & Conflict behavior \\
\hline & & $44 \%$ & $20 \%$ & $36 \%$ \\
\hline
\end{tabular}

On the basis of the data, we were able to draw a number of conclusions. The level of development of the cognitive component of communicative competence of primary school students in the field of language and speech skills, in general, can be assessed as satisfactory. More than half of the students in the experimental and control groups demonstrated intermediate level knowledge $(58 \%$ and $60 \%$ ) in the field of their native language, and below the average level of $35-40 \%$ in the field of a foreign language. In accordance with the standard, students have either an equally low or equally high level of proficiency in language and speech in Russian and in a foreign language. Another part of the cognitive component (such as knowledge of etiquette, cultural and ethnonational traditions associated with good communication practice) is usually formed at lower levels in younger students.

The least favorable picture is observed from the formation of younger students' communicative competence's regulatory and behavioral components. Particularly noteworthy are indicators such as conflict, aggressive behavior in groups (36\%); inability to be polite in communication (36\%); insufficient ability to build their own behavior taking into account the situation (20\%). The results obtained at this stage of the study once again confirm that the potential of primary teaching a foreign language is far from being fully realized in the most important part of the work to develop students' communicative competence, namely due to inefficient attention in a holistic framework. The work is devoted to the formation of its normative-behavioral component, which requires further adjustment of pedagogical technologies of primary education in foreign languages.

To confirm these findings, we conducted an interview with teachers of the junior block, where questions were asked about the formation of younger students' meta-subject results. In this context, teachers talk about the regulatory and behavioral component as the most important in the formation of communication skills in the framework of meta-subject. At the same time, assessing the possibilities of primary teaching a foreign language in the formation of communicative competence, teachers put the components of the cognitive component first. Therefore, in the general system of work on the formation of communicative competence in primary education in a foreign language, special attention should be paid to the regulatory-behavioral and cognitive components. 


\section{Summary}

Based on Russian scientific research (Khutorskoy, 2012; Devyatova, 2018; Barinova, 2013) and foreign (Nielsen, Mathews, 2013; Morpurgo, 2015) scientists, we concluded that the meta-subject approach should be methodologically based on age-related characteristics of child psychology. Foreign language lessons based on meta-subjects represent the formation of the following interdisciplinary cognitive skills in students:

- theoretical thinking (generalization, systematization, the definition of concepts and classification);

- information processing skills (analysis, synthesis, interpretation, evaluation, argumentation and the ability to shorten the information);

- critical thinking (the ability to see logical inconsistencies, unspoken positions, etc.);

- creative thinking (information transferring and projection, the combination of known methods of activity with new ones);

- the quality of thinking (flexibility, ability to transfer the information wider, etc.).

Four groups of strategies are distinguished in the foreign language education of a primary school student in the framework of the meta-subject approach: a) motivating and regulatory strategies (Shapovalova, 2010); b) ICT and psychotechnical strategies based on linguistic-cognitive, linguistic-cultural, and speech-cognitive mechanisms of linguistic activity (Sharapov, 2012); c) visualization strategy as a way to develop a sense of language and language practice; d) strategies of semantic reading as a way of forming discursive - communicative and cognitive skills.

The set's tasks should correspond to age-related characteristics and stimulate their regulatory - behavioral and cognitive activity. The work should include the following educational activities of students:

1. Actualization of the student's life experience.

2. Determining the purpose of the lesson and motivation to solve a problem situation.

3. Inclusion of speech-cognitive and metacognitive activity and creative capabilities of the student.

4. Creation of associations, a semantic image of representations, that is, personal meaning.

5. Reflection and summarising.

In other words, to achieve the set goals, the meta-subject educational activity should be structured so that students act as its active subjects, i.e., they have the skills to search for information, analyze and systematize it, and the ability to visualize the results obtained (for example, infographics). The work results should be presented in the classroom for learning by other students and subsequent collective discussion. It is also essential that the activity approach positively affects the assimilation of educational material and students' personal development.

\section{Conclusions}

The modern system of Russian education, developing in a competence paradigm, puts on the agenda the need for students to develop communicative skills as a communicative competency, classifying it as a critical meta-subject competency. The meta-subject approach is an integrative characteristic, including a set of personality traits that present a person with the ability to act in a given communication situation, willingness and ability to utilize existing experience in solving assigned communicative tasks - at a level determined by age-related psychological characteristics and social experience and capabilities of a primary school student, and taking into account age restrictions of cognitive-speech nature. Another aspect of the meta-subject is the ICT (Information and communication technologies) approach. This approach should be implemented in the context of the modern paradigm of informatization of society, consider the factors of the influence of the information society on students' mental and speech development, and prepare them for future activities in the information world. The prevalence of mosaic thinking in the modern information society means a particular type of perception and processing of information. The presentation of information, in our opinion, should be as close as possible to the type of creolized text, in which the text is presented in the form of essential maxims and is accompanied by visual support - an image. Creolized text is a necessary visual and verbal support in the perception of vast amounts of information.

Meta-subject competencies are also formed in-game situations, for example, in a board game. The knowledge of the vocabulary on the topic and dialogic and spontaneous speech skills are also checked. Besides, in this task, meta-subject knowledge is updated (food, cultural features, and regional geographic remarks).

The meta-subject educational activity contributes, in our opinion, to the formation of the basic principles of critical 
thinking, to the ability to single out the semantic essence of information, to succinctly present it in visual and verbal forms, as well as the ability to analyze it. Thus, the meta-subject approach allows us to actively interpret educational material in particular in the humanitarian profile disciplines.

\section{Acknowledgements}

The work is performed according to the Russian Government Program of Competitive Growth of Kazan Federal University.

\section{References}

Barinova, E. A. (2013). Meta-subject approach in education and meta-subject skills. Training and education: methods and practice; 8 .

Decree of the Ministry of Education and Science of Russia dated December 31, 2015, N 1577 On Amendments to the Federal State Educational Standard of Basic General Education, approved by order of the Ministry of Education and Science of the Russian Federation of December 17, 2010, N 1897.

Decree "On the approval of the federal state educational standard of basic general education", as amended by the order of the Russian Ministry of Education and Science dated December 29, 2014. № 1644.

Devyatova, I. E. (2018). Meta-subject matter as a new value of education. Science and education: preserving the past, creating the future: collection of articles of the XV International scientific-practical conference: in 3 parts, Penza.

Fotekova, A. T. (2007). Testing methodics for the diagnosis of oral speech of primary school students: resource book. Moscow: Iris-Press.

Handabur, O. V., Sliuzko, V. I., Melnyk, R. M., \& Hlushok, L. M. (2020). The Use of Information Technologies for the Development of Competences in Future Teachers of Foreign Language and Foreign Literature. International Journal of Higher Education, 9(7), 6-12. https://doi.org/10.5430/ijhe.v9n7p142

Khutorskoy, A. V. (2012). The meta subject "Numbers": a resource book for elementary school teachers: 2nd ed., revised and added, Moscow: Eidos Publishing House.

Kordts-Freudinger, R. (2017). Feel, Think, Teach - Emotional Underpinnings of Approaches to Teaching in Higher Education. International Journal of Higher Education, 6(1), 3-1. https://doi.org/10.5430/ijhe.v6n1p217

Mathews, J. (2013). A Meta Competency Analysis. https://doi.org/10.2139/ssrn.2363301

Morpurgo, M. T. (2015). Beyond Competency: The role of professional accounting education in the development of meta-competencies, Athabasca University. Dissertation for the degree of Doctor of Business Administration.

Nielsen, R. K. Global Mindset as Managerial Meta-competence and Organizational Capability: Boundary-crossing Leadership Cooperation in the MNC. Retrieved from https://research.cbs.dk/en/publications/global-mindset-as-managerial-meta-competence-and-organizational-c

Rene Gille's testing methodics. Retrieved from http://testoteka.narod.ru/pm/1/05.html

Shapovalova, O. E. (2010). Studying the attitude of primary schoolchildren towards learning Elementary school, 1 , 22-28.

Sharapov, V. N. (2012). Information technology in the process of teaching younger students. Science and School, 5.

Shemshurina, A. I. (1996). The system of ethical education of students. Moscow: LATMES.

Tan, S. Y., D. Al-Jumeily, J., Mustafina, A., Hussain, A., \& Broderick, H. F. (2018). Rethinking our education to face the new industry era. 10th International Conference on Education and New Learning Technologies, 6562-6571. https://doi.org/10.21125/edulearn.2018.1564

UNESCO World Report. Towards Knowledge Societies. Retrieved from https://unesdoc.unesco.org/ark:/48223/pf0000141843?posInSet=2\&queryId=b4e28dc9-18ac-49d4-916e-4e5ca6 $\mathrm{a} 4 \mathrm{a} 8 \mathrm{~b} 3$ 
URL:

https://cyberleninka.ru/article/n/informatsionnye-tehnologii-v-protsesse-obucheniya-mladshih-shkolnikov-1/vie wer

URL: https://legalacts.ru/doc/prikaz-minobrnauki-rossii-ot-29122014-n-1644/

URL: https://legalacts.ru/doc/prikaz-minobrnauki-rossii-ot-31122015-n-1577/

\section{Copyrights}

Copyright for this article is retained by the author(s), with first publication rights granted to the journal.

This is an open-access article distributed under the terms and conditions of the Creative Commons Attribution license (http://creativecommons.org/licenses/by/4.0/). 